\title{
CORRECTION
}

\section{Correction to: Uveal Melanoma: A Review of the Literature}

Manni Singh $\cdot$ Priya Durairaj $\cdot$ Jensen Yeung

Published online: February 5, 2019

(c) The Author(s) 2019

Correction to: Oncol Ther (2018) 6:87-104 https://doi.org/10.1007/s40487018-0056-8

The category of this article was incorrectly published as an Original Research Article, when it should have been published as a Review.

The original article can be found online at https://doi. org/10.1007/s40487-018-0056-8.

M. Singh ( $\varangle)$

University of Toronto, Toronto, ON, Canada

e-mail: manni.singh@mail.utoronto.ca

P. Durairaj

Department of Ocular Oncology, The Princess

Margaret Hospital, Toronto, ON, Canada

J. Yeung

Department of Medicine (Dermatology), University

of Toronto, Toronto, ON, Canada

Open Access. This article is distributed under the terms of the Creative Commons Attribution-NonCommercial 4.0 International License (http://creativecommons.org/licenses/ by-nc/4.0/), which permits any noncommercial use, distribution, and reproduction in any medium, provided you give appropriate credit to the original author(s) and the source, provide a link to the Creative Commons license, and indicate if changes were made. 